\title{
Using clay to control harmful algal blooms: deposition and resuspension of clay/algal flocs
}

\author{
Stace E. Beaulieu ${ }^{1}$, Mario R. Sengco ${ }^{2}$, and Donald M. Anderson ${ }^{2}$ \\ ${ }^{1}$ Applied Ocean Physics and Engineering Department \\ Mail Stop \#7
}

Woods Hole Oceanographic Institution

Woods Hole, MA 02543

Tel: 508-289-3536

Fax: 508-457-2006

stace@whoi.edu

${ }^{2}$ Biology Department

Mail Stop \#32

Woods Hole Oceanographic Institution

Woods Hole, MA 02543

Manuscript revised for Harmful Algae

21 Dec 2003 


\section{Abstract}

Harmful algal blooms (HABs) may be legitimate targets for direct control or mitigation,

3 due to their impacts on commercial fisheries and public health. One promising control strategy

4 is the rapid sedimentation of HABs through flocculation with clay. The objective of this study

5 was to evaluate flow environments in which such a control strategy might be effective in

6 removing harmful algae from the water column and depositing a layer of clay/algal flocs on the

7 sea floor. We simulated the natural environment in two laboratory flumes: a straight-channel

8 "17-m flume" in which flocs settled in a still water column and a "racetrack flume" in which

9 flocs settled in flow. The 17-m flume experiments were designed to estimate the critical bed

10 shear stress for resuspension of flocs that had settled for different time periods. The racetrack

11 flume experiments were designed to examine the deposition and repeated resuspension of flocs

12 in a system with tidal increases in flow speed. All flume runs were conducted with the non-toxic

13 dinoflagellate Heterocapsa triquetra and phosphatic clay (IMC-P4). We repeated the

14 experiments with a coagulant, polyaluminum hydroxychloride (PAC), expected to enhance the

15 removal efficiency of the clay. Our experiments indicated that at low flow speeds $\left(\leq 10 \mathrm{~cm} \mathrm{~s}^{-1}\right)$,

16 phosphatic clay was effective at removing algal cells from the water column, even after repeated

17 resuspension. Once a layer of flocs accumulated on the bed, the consolidation, or dewatering, of

18 the layer over time increased the critical shear stress for resuspension (i.e. decreased erodibility).

19 Resuspension of a 2 -mm thick layer that settled for 3 hours in relatively low flow speeds $(\leq 3 \mathrm{~cm}$

$20 \mathrm{~s}^{-1}$ ) would be expected at bed shear stress of $\sim 0.06-0.07 \mathrm{~Pa}$, as compared to up to $0.09 \mathrm{~Pa}$ for a

21 layer that was undisturbed for 9 or 24 hours. For the same experimental conditions, the addition

22 of PAC decreased the removal efficiency of algal cells in flow and increased the erodibility of

23 flocs from the bottom. By increasing the likelihood that flocs remain in suspension, the addition 
1 of PAC in field trials of clay dispersal might have greater impact on sensitive, filter-feeding organisms. Overall, our experiments suggest that the flow environment should be considered 3 before using clay as a control strategy for HABs in coastal waters.

\section{Key words}

7 flume, harmful algal bloom, Heterocapsa triquetra, phosphatic clay, polyaluminum

8 hydroxychloride, resuspension, sedimentation 


\section{Introduction}

Harmful algal blooms (HABs) pose a serious threat to commercial fisheries and aquaculture, human health, and coastal aesthetics. These phenomena are caused by rapid population growth of microscopic algae, some of which produce toxins. Because of the potentially significant impacts of $\mathrm{HABs}$, these phenomena may be legitimate targets for direct control or mitigation. Perhaps the most promising control strategy, with respect to maximizing effectiveness and minimizing costs and environmental impacts, is flocculation and sedimentation of HABs with clay (Anderson, 1997; Boesch et al., 1997; Anderson et al., 2001; Sengco, 2001). Over the past 25 years, clays have been investigated in several countries as a means of removing harmful algae from the water column (e.g. Shirota, 1989; Yu et al., 1994; Bae et al., 1998). Japan (Shirota, 1989), South Korea (Choi et al., 1998), and Australia (Atkins et al., 2001) already have attempted clay dispersal to control HABs in the field.

Rapid sedimentation of algal cells may be caused by the flocculation (i.e. coagulation; Jackson and Lochmann, 1993) of clay particles with algal cells, the entrainment of algal cells into settling clay flocs, and/or the loss of algal cell motility due to physico-chemical interactions with the clay particles. Upon accumulation in a floc layer on the sea floor, algal cells would be trapped among clay particles, likely resulting in cell mortality (Sengco et al., 2001; A. Li et al., unpub. data; but see Burkholder, 1992 for formation of temporary cysts). A wide variety of laboratory studies in static (i.e. still water) systems have confirmed that clays can effectively remove algal cells from the water column. Early test-tube studies demonstrated that clay/algal flocculation was influenced by mineral type, algal species, and both algal and clay particle concentration (Avnimelech et al., 1982; Soballe and Threlkeld, 1988). Laboratory studies of harmful algal species again showed that some clay minerals were more effective at removing 
1 cells from the water column (e.g. Yu et al., 1995; Sengco et al., 2001), with species-specific

2 variability in removal efficiency (Sengco, 2001).

Although the above studies indicated that clays can be effective in removing algal cells from a static water column, controlled experiments simulating natural flow conditions must be performed to facilitate estimates of the effectiveness of clay application in the field. A recent series of laboratory flume experiments with phosphatic clay indicated that the removal efficiency (RE) of the dinoflagellate Heterocapsa triquetra was enhanced in low flow $\left(\sim 2 \mathrm{~cm} \mathrm{~s}^{-1}\right)$ and greatly reduced in higher flow $\left(\sim 13 \mathrm{~cm} \mathrm{~s}^{-1}\right)$ conditions (Archambault et al., 2003). Flow conditions would influence four major processes that must be considered in evaluating whether clay can mitigate HABs: flocculation, advection, deposition, and resuspension (Fig. 1).

Flocculation, or the formation of clay/algal aggregates (flocs), would result from particle contact (collision) followed by adhesion. The rate of particle contact, in the case of clay/algal flocculation, would be influenced by turbulence intensity, differential settling of particles and flocs, and motility of the algal cells (Jackson and Lochmann, 1993; Sengco, 2001). High rates of shear might also limit the maximum size of flocs, thus limiting settling velocity (e.g. Hill, 1998).

Flocs with lower settling velocities would have a higher probability of remaining suspended in the water column and would be subject to advection, or lateral transport, by currents. These processes, flocculation and advection, were not examined directly in this study. Here, we examined the deposition of clay/algal flocs in flowing water and the potential for flocs to be resuspended after deposition (Events 3 and 4 in Fig. 1).

By inhibiting deposition and/or promoting resuspension, physical forcing from currents and waves has the potential to prolong the residence time of clay/algal flocs in the water column. Initial flume experiments conducted with juvenile bivalves indicated that suspended clay/algal 
1 flocs negatively impacted growth of these sensitive filter-feeding organisms (Archambault et al., 2002). Resuspension also potentially would re-seed the water column with viable cells. In testtube experiments with Karenia brevis and phosphatic clay, cell mortality was not observed after $2.5 \mathrm{hrs}$ in clay loadings up to $0.5 \mathrm{~g} \mathrm{~L}^{-1}$ (thickness of pellet not noted; Sengco et al., 2001). On the other hand, in low flow conditions, a mass deposition of flocs potentially would create a layer

6 of flocs on the sea floor. Organic material in the layer would decompose, potentially leading to anoxia and deleterious effects on benthic fauna. Use of clay in the field would involve a balance between removing harmful algae from the water column and minimizing environmental impacts on benthic fauna. Some laboratory studies in static systems have indicated that cell RE can be enhanced and clay loadings decreased by dispersing coagulants such as polyaluminum

11 hydroxychloride (PAC) in very low concentrations prior to the application of clay (Yu et al., 1995; Sengco et al., 2001). For similar RE of K. brevis, pretreatment with 5 ppm PAC reduced

13 clay loadings by an order of magnitude in still water (Sengco et al., 2001). 
1 flow conditions (mean flow, oscillatory flow, turbulence; list modified from Miller et al., 1977).

2 Because of the cohesive nature and heterogeneous composition of clay/algal flocs, critical shear

3 stresses must be determined empirically. Typical threshold curves (e.g. Shields diagram) for

4 initial motion of sediment assume non-cohesive sediment grains of a single size and

5 homogeneous composition (Miller et al., 1977; Middleton and Southard, 1984).

6 The flume experiments in this study were designed to estimate critical shear stresses for

7 deposition and resuspension of clay/algal flocs, as well as to further study RE in flow. Our main

8 objective was to predict flow environments in which a layer of clay/algal flocs would accumulate

9 on the sea floor. An additional objective was to determine the effect of PAC on the deposition

10 and resuspension of clay/algal flocs. We employed two approaches: 1) settling in a still water

11 column (as might occur during slack tide or in a protected embayment), and 2) settling in flow.

12 These flume studies are an important intermediate step between experiments with test tubes and

13 settling columns in the laboratory and the actual dispersal of clay in the field.

14

15

16

17

18

19

20

21

22

23

\section{Methods}

At the Coastal Research Laboratory of Woods Hole Oceanographic Institution, two different flumes were used in the two separate sets of experiments described below. Fries and Trowbridge (2003) illustrate and describe the mechanics of both of the flumes (for photographs of the flumes, see http://www.whoi.edu/institutes/coi/facilities/coastal_lab.htm). Smoothturbulent benthic boundary layers developed in both flumes (fully-developed at the test sections).

Due to concerns about toxins in the flumes, experiments were conducted with the non-toxic dinoflagellate Heterocapsa triquetra. This species is easy to culture in the laboratory, has a similar size (14.7 $\mu$ m equivalent spherical diameter; Archambault et al., 2003) and shape to 
1 several well-studied harmful algal species (e.g. Karenia brevis; Sengco, 2001), and other species within this genus are known to cause HABs (Matsuyama et al., 2001). Cultures were maintained in 15 - L carboys in $\mathrm{f} / 2$ medium with filtered seawater at constant, high light intensity at $20^{\circ} \mathrm{C}$. All flume runs were conducted at $\sim 20^{\circ} \mathrm{C}$ so as not to shock the algae (Table 1). Phosphatic clay was used in the flume experiments (IMC-P4; IMC Phosphates Company, Lake Forest, IL, U.S.A.). Phosphatic clay, a by-product of phosphate mining operations, is a mixture of clays (esp. montmorillonite) and other minerals (Bromwell, 1982), and, in practice, may be relatively inexpensive, easy to work with, and locally available in the case of HABs of the Florida coast. Phosphatic clay $(<2 \mu \mathrm{m}$ equivalent spherical diameter; Archambault et al., 2003) showed high removal efficiency (RE) for a broad range of algal taxa in test-tube experiments (Sengco, 2001). Flume experiments were repeated with the addition of polyaluminum hydroxychloride, or PAC (Superfloc 9001, Cytec Industries, Inc., West Paterson, NJ, USA), a coagulant used in treatment of drinking water. Neither the clay nor PAC had acute or chronic toxic effects on common estuarine invertebrates and fish (Lewis et al., 2003).

\section{Flocs settling in still water}

17-m flume experimental design. The first set of experiments was conducted in a 17-m long, 60-cm wide, straight, open-channel flume (“17-m flume;” Butman and Chapman, 1989). The 17-m flume experiments were designed to compare the critical bed shear stress $\left(\tau_{\text {ccrit }}\right)$ for resuspension of clay/algal flocs that settled for different time periods. A removable bottom panel with a recessed $20 \times 20 \times 2-\mathrm{cm}$ deep box was placed in the flume, centered at $12.9 \mathrm{~m}$ downstream. The box was filled with sieved sand (250-500 $\mu \mathrm{m})$, leveled $\sim 2 \mathrm{~mm}$ below flush to create the test bed. At the beginning of each experiment, the flume was filled to $12-\mathrm{cm}$ water 
1 depth with $10-\mu \mathrm{m}$ filtered seawater, moving at the slowest possible flow speed $\left(\sim 3 \mathrm{~cm} \mathrm{~s}^{-1}\right)$. An acrylic fence, covered with plastic wrap (or extending above the water surface in the experiments with PAC), was placed around the test bed. A wide-mouthed pipette was used to introduce algae (then PAC) then clay to the enclosed volume of water over the test bed, and flocculation occurred in a relatively still water column. Before introducing $100 \mathrm{~mL}$ of algal culture into the

enclosure, $1 \mathrm{~mL}$ was removed and preserved for cell counts at 200X under a compound microscope. Resulting cell concentrations, determined from triplicate counts of $0.1 \mathrm{~mL}$ aliquots, were $\sim 2 \times 10^{3} \mathrm{~mL}^{-1}$ in the enclosed volume (Table 1). For a final concentration of $5 \mathrm{ppm}\left(\mathrm{mg} \mathrm{L}^{-}\right.$

$\left.{ }^{1}\right)$ PAC in the enclosure, stock solution was first diluted with $100 \mathrm{~mL}$ of deionized water to prevent precipitation which occurs in high concentrations in seawater. The clay was prepared in $200 \mathrm{~mL}$ of filtered seawater by blending and straining through a $63-\mu \mathrm{m}$ sieve. The clay concentrations used in the flume runs necessarily differed among treatments $\left(0.28-0.71 \mathrm{~g} \mathrm{~L}^{-1}\right.$; Table 1), for two reasons. First, in static conditions the thickness of a floc layer decreased with time as the layer dewatered. Exploratory flume runs were conducted to determine the mass of clay necessary for a flush layer on the test bed (Anderson et al., 2003). Second, an objective of these experiments with PAC was to simulate lower clay concentrations in the water column, with the same total mass depositing on the test bed (to control for the thickness of the layer on the bed). In all experiments the areal loadings of clay were less than the $200 \mathrm{~g} \mathrm{~m}^{-2}$ suggested by Shirota (1989) but more appropriate for such a shallow water column (33 - $57 \mathrm{~g} \mathrm{~m}^{-2}$; Table 1). For all of the algal and clay concentrations tested, $\sim 80 \% \mathrm{RE}$ was expected based on previous laboratory tests in still water (Sengco, 2001).

During each experiment a floc layer accumulated on the test bed and consolidated over the treatment period $(3,9$, or $24 \mathrm{hr})$. Overall, the experimental design was a $3 \times 2$ factorial 
1 design with three replicate flume runs for each of the six treatments (Table 1). The analysis of

2 critical shear stress $\left(\tau_{0 c r i t}\right)$ began when the fence was removed, exposing the floc layer to the

3 overlying flow. The test bed surface was illuminated from above with a light sheet $(\sim 2$-cm wide

4 at the bed), and a video camera recorded a section of the flow directly above the test bed. As the

5 flow speed was increased in the flume, the following visual criteria were used for determining

6 three stages of particle transport: initial motion-- when particles (i.e. clay/algal flocs) started

7 rolling on the test bed; bedload-- when most particles were rolling and some were saltating; and

8 resuspension-- when particles were continuously lifting from and not returning to the bed (for

9 video clips of particle transport, see http:/www.whoi.edu/science/B/people/sbeaulieu/FIPR/).

10 For each mode of particle transport, a Laser Doppler Velocimeter (LDV) was used to record a 4-

11 min record of along-channel velocity at $8 \mathrm{~cm}$ above bottom (a.b.).

12 Data analyses for 17-m flume experiments. Bed shear stress $\left(\tau_{0}\right)$ in the $17-\mathrm{m}$ flume derived 13 mainly from the mean flow in combination with a standing wave created by flow rebounding 14 against the weir at the downstream end. Detailed methods for estimating mean shear stress $\left(\bar{\tau}_{0}\right)$

15 and time series of wave-forced shear stress $\widetilde{\tau}_{0}(t)$ in the 17-m flume are described by Beaulieu

16 (2003). Based on the analysis of flow profiles previously measured in the 17-m flume, the mean

17 flow at $8 \mathrm{~cm}$ a.b. $\left(\bar{u}_{8}\right)$ was related to shear velocity $(u *)$ via a drag law for both the mean current

$18\left(\bar{u}_{*}=0.0419 \bar{u}_{8}+0.0574 ; \mathrm{n}=85\right.$ profiles, $\left.\mathrm{r}^{2}=0.99\right)$ and wave boundary layers $\left(\tilde{u}_{*}=0.005 \bar{u}_{8}+\right.$

$190.204 ; \mathrm{n}=39$ records at $1.2 \mathrm{~cm}$ a.b., $\left.\mathrm{r}^{2}=0.78\right)$. Critical shear velocity at each stage of particle

20 transport then was estimated as $u_{*_{c r i t}}=\left(\left(\bar{u}_{*}\right)^{2}+\left(\tilde{u}_{*}\right)^{2}\right)^{1 / 2}$, with critical bed shear stress estimated

21 as $\tau_{0 c r i t}=\rho u_{*_{c r i t}}{ }^{2}$. The technique for estimating $u *_{c r i t}$ was checked by running additional

22 experiments with the test bed filled with sand of the following grain sizes: $125-250 \mu \mathrm{m}, 250-500$ 
$\mu \mathrm{m}$, and 500-1000 $\mu \mathrm{m}$. Estimates of $u_{*_{c} r i t}$ for initial motion of sand compared well to the expected threshold values (Miller et al., 1977). The critical bed shear stress $\left(\tau_{0 c r i t}\right)$ for resuspension is best described as a "resuspension stress" corresponding to a high rate of erosion, rather than a threshold of motion.

Two-way analysis of variance (ANOVA) was used to compare $\tau_{0 c r i t}$ among the six treatments. We used the least significant difference (LSD) procedure for planned multiple comparisons of the mean $\tau_{0 c r i t}$ values. Assumptions of ANOVA were checked with normal probability plots and the Hartley $\mathrm{F}_{\max }$-test for homogeneity of variances. Statistics were conducted with Statistica 5.1 software, tested for significance at $\alpha=0.05$, and are described by Sokal and Rohlf (1981).

\section{Flocs settling in flow}

Racetrack flume experimental design. In the second set of experiments, the natural environment was simulated by dispersing clay on the surface of flowing water seeded with dinoflagellates and then increasing/decreasing flow speed. These experiments were designed to estimate the critical bed shear stresses for deposition and erosion of flocs, as well as to study removal efficiency (RE) in flow. The experiments were conducted in an oval, open-channel flume with channel width $76 \mathrm{~cm}$ and plan area $17.1 \mathrm{~m}^{2}$ ("racetrack flume"). Flow in the racetrack flume is controlled by paddles which enter the water vertically. The total of six experiments explored three different initial flow speeds with and without PAC (Table 1). Replication was not possible due to the need for large culture volumes to seed the 2052-L flume volume. To reduce variability in our measurements (such as algal cell loss or changes in bottom roughness), the test bed was solely the plastic bottom panels. 
Prior to each experiment, the flume was filled to $12-\mathrm{cm}$ water depth with $10-\mu \mathrm{m}$ filtered seawater. We placed optical backscatter sensors (OBS-3; D\&A Instrument Company, Port Townsend, WA, U.S.A.) at 3.4 and $8 \mathrm{~cm}$ above bottom to measure suspended mass in the water column every 10 seconds during the entire flume run. Due to turbidity in the flume, visual criteria could not be used to determine critical shear stresses. Prior to placement in the flume, the OBS sensors were calibrated to suspended mass by mixing clay in five increments of $0.07 \mathrm{~g}$ $\mathrm{L}^{-1}$ in a separate tank filled with filtered seawater (see Bunt et al., 1999 for discussion of OBS calibration). Water samples (10- to 50-mL) from the tank were filtered over pre-weighed GFF filters, rinsed with Milli-Q water, and dried overnight at $60^{\circ} \mathrm{C}$ before re-weighing for dry mass. Also, during the flume runs a "syringe sampler" was directed upstream into the flow at 3.4 and 8 $\mathrm{cm}$ a.b. to collect water samples (10- to $50-\mathrm{mL}$, depending on clay concentration) to check the OBS data with actual measurements of dry mass. The syringe sampler consisted of a PVC support with draw cord that held a $60-\mathrm{mL}$ syringe horizontal above the flume bed (2-mm diam. sample opening).

To begin each experiment, several carboys of algal culture $(50 \mathrm{~L})$ were added to the flume, with paddle speed at $10 \mathrm{~cm} \mathrm{~s}^{-1}$. After $\sim 30$ minutes, syringe samples $(50 \mathrm{~mL})$ were collected at $6 \mathrm{~cm}$ a.b. and preserved to determine the initial cell concentration via triplicate counts of 1-mL aliquots under a compound microscope. Initial algal concentrations in the racetrack flume were similar but slightly less than in the 17-m flume experiments (Table 1). For the flume runs with PAC, stock PAC solution was diluted in $18 \mathrm{~L}$ of deionized water and sprayed at $5 \mathrm{~L} \mathrm{~min}^{-1}$ on the water surface for a final concentration of $5 \mathrm{ppm}$ in the flume. The PAC solution was dispersed in a sweeping motion over $\sim 1 / 3$ of the plan area of the water surface using a sump pump, hose, and "flat" spray nozzle. The paddle speed then was set to 3 or $20 \mathrm{~cm}$ 
$1 \mathrm{~s}^{-1}$ (or remained at $10 \mathrm{~cm} \mathrm{~s}^{-1}$ ) for 30 minutes prior to adding clay to the flume. For a final

2 concentration of $0.28 \mathrm{~g} \mathrm{~L}^{-1}$ in the flume, $1.2 \mathrm{~kg}$ (wet; $47.33 \%$ dry mass) of IMC-P4 clay was

3 blended, strained through a $63-\mu \mathrm{m}$ sieve, suspended in a total of $54 \mathrm{~L}$ of $10-\mu \mathrm{m}$ filtered seawater,

4 and sprayed (as above) at $5 \mathrm{~L} \mathrm{~min}^{-1}$ on the water surface.

For the experiments that started at 3 or $10 \mathrm{~cm} \mathrm{~s}^{-1}$, flocs settled for 3 hours prior to the first resuspension "event" in which paddle speed was increased every five minutes in $1 \mathrm{~cm} \mathrm{~s}^{-1}$

7 increments to $25 \mathrm{~cm} \mathrm{~s}^{-1}$. The second and third resuspension "events" occurred after 3-and 9-hr

8 settling periods, respectively. For the experiments initially at $20 \mathrm{~cm} \mathrm{~s}^{-1}$, the paddle speed was

9 stepped down by $2 \mathrm{~cm} \mathrm{~s}^{-1}$ every 3 hours. Because turbidity in the flume during these

10 experiments precluded the use of an LDV to measure flow speeds, flow profiles at paddle speeds

$113-25 \mathrm{~cm} \mathrm{~s}^{-1}$ were recorded after the flume was cleaned and filled to $12-\mathrm{cm}$ depth with seawater

12 at $20^{\circ} \mathrm{C}$. Also due to turbidity, we were unable to determine the size spectra of flocs during the experiments with a Laser In Situ Scattering and Transmissometry instrument (LISST-100;

14 Sequoia Scientific, Inc., Bellevue, WA, U.S.A.). Water samples for cell counts were withdrawn 15 (as above) just prior to the addition of clay and just prior to each resuspension event. Aliquots

16 (10 to $25 \mathrm{~mL}$ ) of samples with low cell counts were settled in Utermöhl chambers and counted hr period without the addition of PAC or clay.

19 Data analyses for racetrack flume experiments. As shown for other cohesive sediments at 20 concentrations $<0.5 \mathrm{~g} \mathrm{~L}^{-1}$ (Maa et al., 1992), OBS output voltages were linearly proportional to 21 suspended mass at the concentrations used in the racetrack flume experiments $\left(r^{2}=0.99\right.$ for tank calibrations). The OBS values also were well-correlated with suspended mass measured from syringe samples during the flume runs $(n=24, r=0.95, p<0.01)$. Therefore, we used the raw 
1 data from the OBS time series to determine the time during each resuspension event at which: 1) suspended sediment concentration first increased above background level, and 2) maximum input of sediment to the water column occurred, prior to limitation of sediment on the bed

4 (indicated by maximum slope in the OBS record). We calculated the slope of the OBS data via 5 linear fits to all 2-min segments of the time-series records. We assumed that shear stress during

6 1) above was the critical shear stress ( $\left.\tau_{\text {ocrit }}\right)$ for erosion of the flocs, and shear stress during 2 ) above was the stress $\left(\tau_{b}\right)$ at which the maximum erosion rate occurs before supply limitation. Similarly, $\tau_{0 c r i t}$ for deposition, or $\tau_{d}$, of flocs was estimated when suspended sediment concentration first decreased during the flume runs in which flow was stepped down from $20 \mathrm{~cm}$

$10 \mathrm{~s}^{-1}$, with the minimum slope in the OBS record corresponding to the maximum rate of deposition. To calculate bed shear stress during the above observations, the paddle speed $\left(u_{p}\right)$ was associated to both a mean $\left(\bar{u}_{*}\right)$ and wave-forced $\left(\widetilde{u}_{*}\right)$ shear velocity via the following drag laws:

$13 \bar{u}_{*}=0.04 u_{p}+0.0726\left(\mathrm{n}=10\right.$ profiles, $\left.\mathrm{r}^{2}=0.99\right)$ and $\tilde{u}_{*}=0.023 u_{p}+0.1081(\mathrm{n}=11$ records at $14 \quad 1.2 \mathrm{~cm}$ a.b., $\left.\mathrm{r}^{2}=0.97\right)$. Time series of wave-forced shear stress were determined at frequencies

15 based on the paddle speed divided by spacing between the paddles. Total shear velocity $(u *)$ and bed shear stress $\left(\tau_{0}\right)$ then were determined using the equations given previously. For each of the

17 resuspension events, we fit the data to a standard linear erosion model, given by $E=M\left(\tau_{b} / \tau_{0 c r i t}\right.$ 18 1), in which $\mathrm{E}$ is erosion rate $\left(\mathrm{kg} \mathrm{m}^{-2} \mathrm{~s}^{-1}\right)$ and $\mathrm{M}$ is an empirical constant (Sanford and Halka, 19 1993; Sanford and Maa, 2001). Although shear stress is not equal across the entire area of the 20 flume bottom (e.g. near the walls), at $3 \mathrm{~cm} \mathrm{~s}^{-1}$ a floc layer accumulated everywhere except for a $21 \sim 15$-cm section immediately underneath the paddle that extended closest to the bottom. To 22 calculate removal efficiency (RE) of algal cells from the water column, we used the following 
1 equation: $\% \mathrm{RE}=100 \times\left(C_{0}-C_{t}\right) / C_{0}$, in which $C_{0}$ is the cell concentration just prior to clay

2 addition and $C_{t}$ is cell concentration at a later time (e.g. after a 3 -hr settling period).

3

4

\section{Results}

\section{Flocs settling in still water}

During the 17-m flume experiments, the bulk of the flocs in the enclosed volume settled to the test bed in $\sim 15$ minutes. Once exposed to flow, initial motion occurred at about $25 \%$ the resuspension stress (half the flow speed) and bedload at about $40 \%$ the resuspension stress (Table 2). Overall, resuspension stress ranged by a factor of 1.5 , from $0.059 \mathrm{~Pa}\left(u *=0.76 \mathrm{~cm} \mathrm{~s}^{-}\right.$ 1; 3-hr settling with PAC) to $0.088 \mathrm{~Pa}\left(u_{*}=0.93 \mathrm{~cm} \mathrm{~s}^{-1} ; 24-\mathrm{hr}\right.$ settling without PAC). Critical shear stresses $\left(\tau_{0 c r i t}\right)$ for bedload and resuspension of clay/algal flocs differed among the six experimental treatments (Table 2). Both factors (settling time and PAC) were significant in the two-way ANOVA for resuspension stress (with no interaction effect; Table 3). Multiple comparisons of the mean values for resuspension stress (plotted in Fig. 2) revealed the following, with treatments listed in order of $\tau_{0 c r i t}$ increasing to the right and nonsignificant differences connected with an underline:

$\underline{3 P A C}<\underline{9 P A C} 324 \mathrm{PAC}<\underline{9} 24$. These results suggest that the greatest increase in consolidation for the 2-mm thick layer occurred between 3 and 9 hours. For a given settling time, $\tau_{0 c r i t}$ was lower in the runs with PAC, although this factor was not significant in a two-way ANOVA of $\tau_{0 \text { crit }}$ for bedload $(\mathrm{p}=0.08)$. 
A floc layer accumulated on the racetrack flume bed during experiments with the paddle speed at 3 and $10 \mathrm{~cm} \mathrm{~s}^{-1}$. For these experiments with subsequent increases in flow speed to simulate tides, OBS records clearly show three periods of settling followed by resuspension "events" (Fig. 3A-D; only one of the OBS sensors yielded accurate data without drift). At $3 \mathrm{~cm}$ $\mathrm{s}^{-1}$ the bulk of the flocs settled in $<1$ hour. At $10 \mathrm{~cm} \mathrm{~s}^{-1}$ many of the flocs had not settled even after 9 hours (especially evident in the run with PAC). As an example of OBS "slope analysis," Figure 4 shows how $\tau_{0 c r i t}$ and $\tau_{b}$ at the maximum erosion rate were determined during the first resuspension event for the flume run that started at $3 \mathrm{~cm} \mathrm{~s}^{-1}$ without PAC. The first increase in slope in Figure 4 occurred when $\tau_{0 c r i t}=0.040 \mathrm{~Pa}\left(u *_{\text {crit }}=0.63 \mathrm{~cm} \mathrm{~s}^{-1}\right.$; paddle speed $\left.11 \mathrm{~cm} \mathrm{~s}^{-1}\right)$. The maximum slope in Figure 4, indicating maximum erosion rate prior to sediment limitation on the bed, occurred at $\tau_{b}=0.060 \mathrm{~Pa}\left(u *=0.76 \mathrm{~cm} \mathrm{~s}^{-1}\right.$; paddle speed $\left.14 \mathrm{~cm} \mathrm{~s}^{-1}\right)$. Table 4 lists these shear stresses for all the resuspension events during the racetrack flume experiments, as well as the slope, M, calculated for the linear erosion rate model. For each experimental treatment, there was very little to no difference in $\tau_{0 c r i t}$ among the three resuspension events. In general, the $\tau_{0 \text { crit }}$ values during the runs that started at $3 \mathrm{~cm} \mathrm{~s}^{-1}$ were slightly greater than $\tau_{0 c r i t}$ for bedload in the 17-m flume experiments, and the $\tau_{0 c r i t}$ values during the runs that started at $10 \mathrm{~cm}$ $\mathrm{s}^{-1}$ were slightly less than resuspension stress in the 17-m flume experiments (compare to Table 2). For the runs that started at $3 \mathrm{~cm} \mathrm{~s}^{-1}$, although there was no difference in $\tau_{0 \text { crit }}$ with presence/absence of PAC, the addition of PAC yielded maximum erosion rates at lower shear stresses (higher values for M; Table 4). In contrast, for the runs that started at $10 \mathrm{~cm} \mathrm{~s}^{-1}$, the addition of PAC lowered $\tau_{0 \text { crit }}$ and also lowered the erosion rate constant, $\mathrm{M}$ (however, note the much lower increase in suspended sediment concentration due to reduced deposition during the run with PAC; Table 4). 
For the experiments that started at $20 \mathrm{~cm} \mathrm{~s}^{-1}$, significant deposition did not occur until the paddle speed was stepped down to $12 \mathrm{~cm} \mathrm{~s}^{-1}$ (arrow in Fig. 3E; one of the experiments ended prematurely with a power outage). At $12 \mathrm{~cm} \mathrm{~s}^{-1}$, a layer began to accumulate on the bed, indicating $\tau_{0 c r i t}$ for deposition, or $\tau_{d}=0.046 \mathrm{~Pa}\left(u_{*_{c r i t}}=0.67 \mathrm{~cm} \mathrm{~s}^{-1} ; 14-18 \%\right.$ mass deposition $)$. Very little (2-8\%) mass deposited while the paddle speed was at $14 \mathrm{~cm} \mathrm{~s}^{-1}\left(\tau_{0}=0.060 \mathrm{~Pa} ; u^{*}=\right.$ $0.76 \mathrm{~cm} \mathrm{~s}^{-1}$ ). With the paddle speed at $10 \mathrm{~cm} \mathrm{~s}^{-1}$, the minimum slope of the OBS record indicated the maximum deposition rate at $\tau_{\mathrm{b}}=0.034 \mathrm{~Pa}\left(u *=0.58 \mathrm{~cm} \mathrm{~s}^{-1} ; 51 \%\right.$ mass deposition $)$. After the 3-hr settling period at $8 \mathrm{~cm} \mathrm{~s}^{-1}, 84 \%$ of the mass deposited.

In the absence of PAC at both 3 and $10 \mathrm{~cm} \mathrm{~s}^{-1}$, algal cell counts were greatly reduced during all settling periods, with removal efficiencies (RE) exceeding $~ 80 \%$ (Fig. 5 and Table 5). However, removal efficiencies were considerably lower when the experiments were repeated with PAC (15-78\%; Table 5). In the absence of PAC, algal cell RE was slightly greater than the percentage of clay mass that deposited to the flume bed (Table 5). In contrast, in the presence of PAC, algal cell RE tended to be less than the percentage of mass deposited (Table 5). Both experiments at $3 \mathrm{~cm} \mathrm{~s}^{-1}$ had the same percentage of clay mass deposited, but mass deposition was lower in the presence of PAC in the experiments at $10 \mathrm{~cm} \mathrm{~s}^{-1}$. Among the three settling periods there was little change in either the percentage of clay deposited or RE in the absence of PAC. In contrast, during the runs with PAC there were large differences in RE among the settling periods, with far more cells removed during the first settling period for the run at $3 \mathrm{~cm} \mathrm{~s}^{-1}$ and during the final settling period for the run at $10 \mathrm{~cm} \mathrm{~s}^{-1}$. Although no mass was deposited with the flow at $20 \mathrm{~cm} \mathrm{~s}^{-1}$, cell counts were considerably lower 3 hours after clay addition, possibly because clay in the water sample precluded accurate cell counts. 


\section{Discussion}

\section{Deposition of clay/algal flocs}

The $\tau_{0 c r i t}$ for deposition, or $\tau_{\mathrm{d}}$, can be used to estimate an upper limit for mean flow speeds that would enable the accumulation of a floc layer on the sea floor. With $\tau_{d}=0.046 \mathrm{~Pa}$ $\left(u_{*}{ }_{\text {crit }}=0.67 \mathrm{~cm} \mathrm{~s}^{-1}\right)$ and assuming a typical quadratic drag coefficient $\left(\mathrm{C}_{D}=\bar{u}_{*}{ }^{2} / \bar{u}^{2}=0.0025\right)$, deposition would be expected at mean horizontal flow speeds $\leq 13 \mathrm{~cm} \mathrm{~s}^{-1}$ in the field (measured just above the bottom boundary layer). Mean flow speed would need to be even lower for significant accumulation of flocs that formed in the presence of PAC. Such flow speeds would be encountered in protected harbors, coastal embayments with muddy bottoms, and in more energetic environments at slack tide. In environments with flow speeds generally $>13 \mathrm{~cm} \mathrm{~s}^{-1}$ ( 1/4 knot), such as sandy nearshore systems or tidal channels, clay/algal flocs likely would remain in suspension.

Settling would be expected if the settling velocity $\left(w_{s}\right)$ of flocs scaled to (or was larger than) vertical fluctuations in flow velocity (an indication of turbulence in the water column), and deposition would be expected if $w_{s}$ scaled to (or was larger than) the shear velocity at the bed (Middleton and Southard, 1984). Although not measured during the flume experiments, a very rough estimate of $w_{s}$ is $2 \mathrm{~mm} \mathrm{~s}^{-1}(12 \mathrm{~cm} / 15 \mathrm{~min})$ during the $17-\mathrm{m}$ flume runs (in still water) and $0.5 \mathrm{~mm} \mathrm{~s}^{-1}(12 \mathrm{~cm} / 1 \mathrm{hr})$ during the racetrack flume runs at $3 \mathrm{~cm} \mathrm{~s}^{-1}$. With $w_{s}=0.5-2 \mathrm{~mm} \mathrm{~s}^{-1}$, flocs would settle through a still water column with depth 5.4 - $21.6 \mathrm{~m}$ in three hours (e.g. during slack tide). These rough estimates for $w_{s}$ for clay/algal flocs compare well to the range (0.3 - 4 $\mathrm{mm} \mathrm{s}^{-1}$ ) determined empirically for phosphatic clay at $0.25 \mathrm{~g} \mathrm{~L}^{-1}$ and Karenia brevis at $10^{4}$ cells $\mathrm{mL}^{-1}$ in settling columns in our laboratory (Anderson et al., 2003). As an additional estimate of $w_{s}$, we used a deposition rate model (Sanford and Halka, 1993), $\mathrm{D}=w_{s} \mathrm{c}\left(1-\tau_{\mathrm{b}} / \tau_{\mathrm{d}}\right)$, in which $\mathrm{c}$ is 
suspended mass concentration prior to stepping down the paddle speed in the racetrack flume from 12 to $10 \mathrm{~cm} \mathrm{~s}^{-1}$. The model yielded a much lower estimate of $w_{s}\left(0.03 \mathrm{~mm} \mathrm{~s}^{-1}\right)$.

In flowing water, turbulence potentially would limit the maximum size of flocs, therefore limiting maximum $w_{s}$ (e.g. Hill, 1998). The size of flocs would be a balance between aggregation (coagulation as a result of shear, differential sedimentation, and algal motility; Jackson and Lochmann, 1993) and disaggregation (due to higher shear as well as biological processes; e.g. Alldredge et al., 1990; Milligan and Hill, 1998). However, floc disaggregation due to turbulence occurs only in very high levels of shear in the marine environment (Alldredge et al., 1990; Hill et al., 2001). Shear rates in the coastal ocean range on the order of $0.01-10 \mathrm{~s}^{-1}$ (Alldredge et al., 1990), with high values in turbulent benthic boundary layers (e.g. Shaw et al., 2001) and tidal channels (e.g. Lueck and Huang, 1999). Although we did not specifically measure turbulence in the racetrack flume, we can estimate the rate of turbulent energy dissipation $(\varepsilon)$ as $\varepsilon \approx\left[\bar{u}_{*}^{3} /(\kappa z)\right](1-z / h)$, in which $\kappa$ is von Karman's constant $(0.41), z$ is height above bottom (we chose half the water depth) and $h$ is water depth in the depth-limited boundary layer (Nezu and Nakagawa, 1993). Shear rate $(G)$ then can be estimated as $G \approx(\varepsilon / v)^{1 / 2}(\mathrm{e} . \mathrm{g}$. Alldredge et al., 1990; Milligan and Hill, 1998). Shear rate $(G)$ during the racetrack flume experiments ranged an order of magnitude from $0.4-5 \mathrm{~s}^{-1}$ (for paddle speeds $3-25 \mathrm{~cm} \mathrm{~s}^{-1}$ ), which is representative of natural conditions and likely did not limit floc size. Size spectra and porosity of flocs were not measured during the racetrack flume experiments. In other flume experiments with phosphatic clay and $H$. triquetra, floc size ranged two orders of magnitude from $10^{0}-10^{2} \mu \mathrm{m}$ (Archambault et al., 2003). Calculations using Stokes Law and empirical values for $w_{s}$ yielded a similar size range for flocs in settling column experiments with phosphatic clay and K. brevis (Anderson et al., 2003). More porous aggregates would lead to 
1 weaker dependence of size to settling velocity predicted by Stokes Law (e.g. Hill, 1998). This

may be the case for flocs that form in the presence of PAC, in which "the bridge linkage of PAC increases effective diameter of clay particles" (translation of Yu et al., 1995).

Interestingly, the critical stress for deposition $\left(\tau_{d}\right)$ was greater than the critical stress for erosion $\left(\tau_{0 c r i t}\right)$ in the racetrack flume experiments $(0.046$ vs. $0.034 \mathrm{~Pa})$, an observation sometimes reported in field studies of cohesive sediments (Sanford and Halka, 1993). Some deposition also occurred at the shear stress that yielded maximum erosion rates in the experiment without PAC at $3 \mathrm{~cm} \mathrm{~s}^{-1}(0.060 \mathrm{~Pa}$; Table 4$)$; however, this may be a result of deposition near the walls of the flume in lower shear stress. In practice in the field, spatial (e.g. depressions on the sea floor) and temporal (e.g. waves) variability in shear stress must be considered in predicting deposition of clay/algal flocs.

We must acknowledge some limitations in interpreting results of settling and deposition in the racetrack flume. More shear would be expected in the turbulent boundary layer of the flume than in the upper water column where initial flocculation would occur in the field. In the field larger flocs might form in the less turbulent upper water column and settle more rapidly than in the flume at equivalent mean flow speeds. Also, in the field deposition of the flocs might not be required for cell mortality (or decreased cell growth) if the settling is effective in transporting algae to darker conditions lower in the water column or if merely being trapped in a floc decreases cell viability. Finally, due to the shallow water depth in the flume, deposition of flocs to the flume bed might be enhanced over natural conditions, since deposition rate is a function of concentration just above the sediment/water interface (Sanford and Halka, 1993).

\section{Resuspension of clay/algal flocs}


Once deposited on the flume bed, clay/algal flocs were more difficult to resuspend the longer they remained in a layer on the bottom. The decrease in erodibility with settling time (3 vs. 9 and $24 \mathrm{hr}$ ) likely was due to consolidation (dewatering) of the floc layer. Dewatering, which decreases the porosity of the floc layer, has been shown in other studies to effectively increase $\tau_{\text {ccrit }}$ of sediments (Mehta, 1989; Sanford and Maa, 2001). Assuming a quadratic drag coefficient as above, resuspension of a 2-mm thick floc layer that settled for 3 hours at relatively low flow speeds $\left(\leq 3 \mathrm{~cm} \mathrm{~s}^{-1}\right)$ would be expected at $15-16 \mathrm{~cm} \mathrm{~s}^{-1}$ in the field, as compared to 18$19 \mathrm{~cm} \mathrm{~s}^{-1}$ for a layer that accumulated in 9 or 24 hours (in the absence of PAC). Results for initial motion suggested that the layer would not erode at all if mean flow speeds were $<8 \mathrm{~cm} \mathrm{~s}^{-1}$ (again, using the quadratic drag coefficient). Resuspension of flocs that settled in faster flow conditions (i.e. $\sim 10 \mathrm{~cm} \mathrm{~s}^{-1}$ ) would be expected at faster mean flow speeds, likely due to hydraulic sorting in which the flocs with greater settling velocity (i.e. larger flocs) are deposited while smaller flocs remained in suspension (Table 5). However, for all of these estimates it is important to consider waves, and not just the mean flow speed, when determining whether a material will erode from the sea floor in many coastal areas. It is also important to consider the thickness of the layer that accumulates on the sea floor. In general, $\tau_{\text {ccrit }}$ increases with depth of erosion in a layer of consolidated sediment (Mehta, 1989; Sanford and Maa, 2001).

When flocs settled in low flow $\left(\leq 3 \mathrm{~cm} \mathrm{~s}^{-1}\right)$, PAC enhanced the entrainment (lowered the resuspension stress and increased the erosion rate) of clay/algal flocs into the water column. Resuspension of flocs that settled with PAC would be expected at slightly lower mean flow speeds (e.g. 14-15 $\mathrm{cm} \mathrm{s}^{-1}$ for flocs that settled in low flow and consolidated for three hours on the sea floor). PAC may have increased the porosity of flocs, which would translate to increased 
1 porosity of the layer that accumulated on the bed, and, consequently, enhanced erosion rates at

2 lower bed shear stresses (e.g. Mehta, 1989; Sanford and Maa, 2001).

Interestingly, values for resuspension stress for clay/algal flocs in the 17-m flume

4 experiments were consistent with values estimated in other studies of "fluff" layers composed of a mixture of sediment and phytodetritus (listed by Beaulieu, 2003). Also, values for the erosion rate constant, $\mathrm{M}$, during the racetrack flume runs without PAC (Table 4) were consistent with field studies of cohesive sediments (e.g. $2.8-12 \mathrm{mg} \mathrm{cm}^{-2} \mathrm{hr}^{-1}$ in Sanford and Halka, 1993). However, we must acknowledge limitations of both flumes in predicting resuspension of flocs in the field. Estimates of $\tau_{\text {ocrit }}$ for flocs in the $17-\mathrm{m}$ flume experiments may have been biased by the lack of turbulence during settling and the lack of wave energy during consolidation. Values for shear stress in the racetrack flume may be biased due to calibration to paddle speed without clay in the flume. However, stratification effects on bed shear stress should be negligible due to the low value of depth-averaged sediment concentration during our flume runs (e.g. Piedra-Cueva et al., 1997). Estimates of $\tau_{0 c r i t}$ and erosion rate for flocs in the racetrack flume may have been biased by lower cohesion of the floc layer to the plastic test bed vs. a natural sediment surface. In addition, in the field bed roughness such as ripples would lead to spatial variability in shear stress, and consequently, spatial variability in erosion of flocs from the sea floor. Also, the flume experiments lacked biota such as microphytobenthos which might stabilize the bed (e.g.

Sutherland et al., 1998) and benthic fauna whose activities (bioturbation) might enhance mixing of clay/algal flocs with ambient sediment or enhance resuspension by destabilizing bed sediment (e.g. Willows et al., 1998). 
Overall, experiments in the racetrack flume suggest that clay can be effective at removing

2 algal cells from the water column in flows up to $\sim 10 \mathrm{~cm} \mathrm{~s}^{-1}$ (in the absence of PAC). The

extremely high cell removal efficiency (RE) at low flow (essentially $100 \%$ at $3 \mathrm{~cm} \mathrm{~s}^{-1}$ ) far exceeded expectations for such low cell concentrations, based on still-water experiments with $H$. triquetra at phosphatic clay loadings of $0.25 \mathrm{~g} \mathrm{~L}^{-1}$ ( 30\%; Sengco, 2001). This enhancement likely is due to enhanced particle contact rate due to shear in the flowing water (e.g. Mehta, 1989; Jackson and Lochmann, 1993). Other flume experiments also found that $\sim 100 \%$ of $H$. triquetra cells were removed by phosphatic clay in a low flow $\left(\sim 2 \mathrm{~cm} \mathrm{~s}^{-1}\right)$ regime, while cells remained in the water column in a higher flow regime $\left(\sim 13 \mathrm{~cm} \mathrm{~s}^{-1}\right.$; Archambault et al., 2003). These results suggest that if flow speeds are low, high cell RE may be achieved with relatively low clay loadings in the field, potentially reducing costs and environmental impacts. Still-water experiments indicated that PAC also might be a means to enhance RE and reduce clay loadings (e.g. Yu et al., 1995; Sengco et al., 2001). However, when racetrack flume experiments were repeated with PAC, RE was much lower and more variable. A tentative explanation for this result is that PAC enhances clay/clay flocculation into porous aggregates that sweep algal cells as they settle through the water column. During the flume run in which initial flocculation occurred at $3 \mathrm{~cm} \mathrm{~s}^{-1}$, porous clay/clay aggregates might have enabled cells to "escape" following the first resuspension event. However, this would not explain how during the experiment at $10 \mathrm{~cm} \mathrm{~s}^{-1}$ with PAC, the greatest RE occurred during the $3^{\text {rd }}$ settling period. Perhaps some cells were damaged due to increased particle collisions at higher shear (which might also explain why some cell removal was observed during the flume run at $20 \mathrm{~cm} \mathrm{~s}^{-1}$ ). Although our results are suggestive of increased clay/algal flocculation in shear flow, we did not determine the exact mechanism for the enhanced RE. Microscopic observations during 
1 other flume experiments (with flow driven by a propeller) did not find evidence for clay/algal

2 flocculation, and the mechanism of cell removal from the water column was undetermined

3 (Archambault et al., 2003). However, microscopic examinations in still-water studies showed

4 clay and algae in flocs (Avnimelech et al., 1982; Shirota, 1989; Burkholder, 1992) and/or

5 mineral particles attached to algal cells (Soballe and Threlkeld, 1988; Yu et al., 1994; Bae et al.,

6 1998). Future flume studies should check for motility and viability of cells flocculating with

7 clay or swept by clay aggregates. Although some studies have shown that cells trapped in a floc

8 layer for three hours were killed ( $>85 \%$ of Pfiesteria piscicida; $\mathrm{A}$. Li et al., unpub. data),

9 Burkholder (1992) found that some dinoflagellates can survive episodic sediment loading by

10 forming temporary cysts. Firm conclusions about the process of clay/algal flocculation in flow

11 and RE in flow must be drawn from replicated experiments, with controls, and with appropriate

12 microscopic examination of fresh samples.

13

\section{Implications for using clay to control HABs}

A conservative look at our results suggests that in environments with low mean flow ( $\leq$ $\left.10 \mathrm{~cm} \mathrm{~s}^{-1}\right)$ and low bed shear stress $(\leq 0.034 \mathrm{~Pa})$, the application of phosphatic clay would lead to $\mathrm{HAB}$ cell sedimentation and the accumulation of a clay/algal floc layer on the sea floor. Using the resuspension stress as an upper limit, some deposition of phosphatic clay would be expected with mean flow up to $\sim 15 \mathrm{~cm} \mathrm{~s}^{-1}$ and bed shear stress up to $0.060 \mathrm{~Pa}$; however, we did not adequately test for algal RE at mean flow $>10 \mathrm{~cm} \mathrm{~s}^{-1}$. In higher flow regimes a floc layer may not accumulate on the sea floor, but cells may still be trapped in flocs in the water column, potentially impairing cell viability. Future studies should be conducted to determine whether 
1 clay and algae flocculate and remain aggregated in suspension at higher flow speeds (e.g. 10 $\left.2100 \mathrm{~cm} \mathrm{~s}^{-1}\right)$.

As a natural component of marine sediments, clay might be expected to cause fewer environmental impacts than other direct control strategies for HABs (e.g. chemical or biological control; Anderson, 1997; Boesch et al., 1997; Anderson et al., 2001). However, clay/algal flocculation, settling, and deposition (Fig. 1) would be likely to affect other planktonic species in the water column as well as organisms on the sea floor. During flocculation and settling, the clay might adhere to organisms other than the targeted harmful algal species. Turbidity in the water column might decrease primary productivity of benign algal species and also decrease feeding activity of visual predators such as larval fish. Although fish exposed to suspended clay for short time periods $(<1 \mathrm{hr})$ were not adversely affected (Shirota, 1989), clay may have effects over longer time periods if flocs remain in suspension. For example, chronic suspension of clay/algal flocs had detrimental effects on suspension-feeding bivalves in a 14-day exposure, although these same organisms were not negatively affected (smothered) by deposition of a layer in low flow (they extended their siphons through the floc layer; Archambault et al., 2002). Deposition of clay/algal flocs would cause at least a temporary change in the physical and chemical composition of the sediments that might affect deposit feeders, settlement of larvae, and chemical fluxes across the sediment/water interface. Depending upon the biological oxygen demand of the deposit, decomposition might lead to anoxia. Experiments with sediment cores taken from the field have shown, however, that the micro- and meio-benthos of sandy sediment can quickly adapt ( $\sim 1$ week) to the deposition of a $2.5-\mathrm{mm}$ layer of carbon-rich silt on the sediment surface, with benthic diatoms restoring the oxygen in the uppermost sediments (Wulff et al., 1997). 
In practice, clays have been used to control HABs in Japan, South Korea, and Australia.

Limited details of clay dispersal and measurement of algal RE in Japanese and Korean field trials have been translated into English. In general, Japan and Korea used clay to protect fish mariculture facilities. Trials in Japan led to the only published observations of the accumulation of clay on the sea floor, in which a diver observed clay on the sea floor at 20-m depth after clay dispersal at $1 \mathrm{~kg} \mathrm{~m}^{-2}$ (corresponds to homogeneous loading of $0.05 \mathrm{~g} \mathrm{~L}^{-1}$ in $1 \times 1 \mathrm{~m}$ column) during flow at $5 \mathrm{~cm} \mathrm{~s}^{-1}$ (Shirota, 1989; photos of vertical sections of sediment cores in Shirota, 1998). In South Korea, dispersal of $10 \mathrm{~g} \mathrm{~L}^{-1}$ yellow loess in the vicinity of fish farms yielded 19 - 58\% reduction in chlorophyll $a$ (Bae et al., 1998) and RE $\sim 80 \%$ for Cochlodinium sp. (Choi et al., 1998). Korea dispersed on the order of $10^{5}$ tons of yellow loess in 1996 and 1997 (Anderson et al., 2001) and 2002 (Raloff, 2002) to combat HABs. In Australia, application of bentonite clay mixed with PAC appeared to be "promising" in treating a cyanobacteria (Microcystis aeruginosa) bloom (no details on clay loading or algal RE; Atkins et al., 2001).

Direct control of HABs is a sensitive issue (e.g. Anderson, 1997; Boesch et al., 1997). Arguments against controlling HABs, discussed by Anderson et al. (2001), include the concern that controlling HABs through a human-introduced disturbance might cause more harm to the environment than it is intended to prevent. However, in some cases short-term, negative impacts might be tolerable when compared to long-term economic and ecosystem impacts, such as those occurring if a bloom persists and affects other locations through time. Small-scale clay dispersal in the vicinity of aquaculture facilities or in a restricted area might be effective in mitigating HABs, particularly with repeated applications. Such a control effort could be justified if sufficient information on procedures, appropriate clay loadings, and environmental impacts were obtained from flume and mesocosm experiments. In evaluating the flume experiments in this 
1 paper, we must acknowledge that results are specific to Heterocapsa triquetra and phosphatic

2 clay, at the concentrations tested. In still-water experiments, RE varied with clay composition,

3 algal species, and clay and cell concentrations (e.g. Avnimelech et al., 1982; Yu et al., 1994,

4 1995; Sengco et al., 2001). Additional flume experiments would be required to evaluate the

5 critical bed shear stresses and RE of other clays in flow. 

We thank C. DiBacco and D. Kulis for help with algal cultures, S. Faluotico, S. Fries,

3 A. Li, J. Savage, J. Sisson, and P. Traykovski for help with flume experiments, and J.

4 Trowbridge for guidance in analyzing wave-forced bottom stress in the flumes. We also thank S.

5 Fries, P. Traykovski, L. Sanford, and two anonymous reviewers for improving the manuscript.

6 This project was funded by the Florida Institute of Phosphate Research (Grant \# 99-03-138),

7 with facilities provided by the Rinehart Coastal Research Center at WHOI. This is WHOI

8 Contribution No. 10960. 


\section{References}

Alldredge, A.L., Granata, T.C., Gotschalk, C.C., Dickey, T.D., 1990. The physical strength of marine snow and its implications for particle disaggregation in the ocean. Limnol. Oceanogr. $35(7), 1415-1428$.

Anderson, D.M., 1997. Turning back the harmful red tide. Nature 388, 513-514.

Anderson, D.M., Andersen, P., Bricelj, V.M., Cullen, J.J., Rensel, J.E., 2001. Monitoring and management strategies for harmful algal blooms in coastal waters. APEC \#201-MR-01.1, Asia Pacific Economic Program, Singapore and Intergovernmental Oceanographic Commission Technical Series No. 59, Paris.

Anderson, D.M., Sengco, M.R., Li, A., Beaulieu, S.E., 2003. Control of Florida red-tides using phosphatic clay: final report. Florida Institute of Phosphate Research. IN REVIEW.

Archambault, M.-C., Bricelj, V.M., Grant, J., Anderson, D.M., 2002. Effects of clay, used to control harmful algal blooms, on juvenile Mercenaria mercenaria. J. Shellfish Res. 21(1), 395396.

Archambault, M.-C., Grant, J., Bricelj, V.M., 2003. Removal efficiency of the dinoflagellate Heterocapsa triquetra by phosphatic clay and implications for the mitigation of harmful algal blooms. Mar. Ecol. Prog. Ser. 253: 97-109.

Atkins, R., Rose, T., Brown, R.S., Robb, M., 2001. The Microcystis cyanobacteria bloom in the Swan River - February 2000. Water Sci. Technol. 43(9), 107-114.

Avnimelech, Y., Troeger, B.W., Reed, L.W., 1982. Mutual flocculation of algae and clay: evidence and implications. Science 216(4541), 63-65. 
Bae, H.M., Choi, H.G., Lee, W.C., Yoon, S.J., 1998. Control of the red tide by yellow loess dispersion. In: Kim, H.G., Lee, S.G., Lee, C.K. (Eds.), Proceedings of Korea-China Joint Symposium on Harmful Algal Blooms. National Fisheries Research and Development Institute, Pusan, Korea, pp. 53-60.

Beaulieu, S.E., 2003. Resuspension of phytodetritus from the sea floor: A laboratory flume study. Limnol. Oceanogr. 48(3), 1235-1244.

Boesch, D.F., Anderson, D.M., Horner, R.A., Shumway, S.E., Tester, P.A., Whitledge, T.E., 1997. Harmful algal blooms in coastal waters: options for prevention, control, and mitigation. NOAA Coastal Ocean Program Decision Analysis Series No. 10, NOAA Coastal Ocean Office, Silver Spring, MD.

Bromwell, L., 1982. Physico-chemical properties of Florida phosphatic clays. Publication No. 02-003-020 National Technical Information Service.

Bunt, J.A.C., Larcombe, P., Jago, C.F., 1999. Quantifying the response of optical backscatter devices and transmissometers to variations in suspended particulate matter. Cont. Shelf Res. 19(9), 1199-1220.

Burkholder, J.M., 1992. Phytoplankton and episodic suspended sediment loading: Phosphate partitioning and mechanisms for survival. Limnol. Oceanogr. 37(5), 974-988.

Butman, C.A., Chapman, R.J., 1989. The 17-meter flume at the Coastal Research Laboratory. Part I: Description and user's manual. Technical Report \#89-10, Woods Hole Oceanographic Institution, Woods Hole, Massachusetts.

Choi, H.G., Kim, P.J., Lee, W.C., Yun, S.J., Kim, H.G., Lee, H.J., 1998. Removal efficiency of Cochlodinium polykrikoides by yellow loess. J. Korean Fish. Soc. 31(1), 109-113. 
Fries, J.S., Trowbridge, J.H., 2003. Flume observations of enhanced fine-particle deposition to permeable sediment beds. Limnol. Oceanogr. 48(2), 802-812.

Hill, P.S., 1998. Controls on floc size in the sea. Oceanography 11(2), 13-18.

Hill, P.S., Voulgaris, G., Trowbridge, J.H., 2001. Controls on floc size in a continental shelf bottom boundary layer. J. Geophys. Res. 106(C5), 9543-9549.

Jackson, G.A., Lochmann, S., 1993. Modeling coagulation of algae in marine ecosystems. In: Buffle, J., v. Leeuwen, H.P. (Eds.), Environmental particles. Environmental, analytical, and physical chemistry. Lewis Publishers, Boca Raton, pp. 387-414.

Lewis, M.A., Dantin, D.D., Walker, C.C., Kurtz, J.C. and Greene, R.M., 2003. Toxicity of clay flocculation of the toxic dinoflagellate, Karenia brevis, to estuarine invertebrates and fish. Harmful Algae 2(4), 235-246.

Lueck, R., Huang, D., 1999. Dissipation measurement with a moored instrument in a swift tidal channel. J. Atmos. Ocean. Technol. 16, 1499-1505.

Maa, J.P.-Y., Xu, J., Victor, M., 1992. Notes on the performance of an optical backscatter sensor for cohesive sediments. Mar. Geol. 104, 215-218.

Matsuyama, Y., Uchida, T., Honjo, T., Shumway, S.E., 2001. Impacts of the harmful dinoflagellate, Heterocapsa circularisquama, on shellfish aquaculture in Japan. J. Shellfish Res. 20(3), 1269-1272.

Mehta, A.J., 1989. On estuarine cohesive sediment suspension behavior. J. Geophys. Res. 94(C10), 14303-14314.

Middleton, G.V., Southard, J.B., 1984. Mechanics of sediment movement. Lecture Notes for Society of Economic Paleontologists and Mineralogists Short Course No. 3, 401 pp. 
Miller, M.C., McCave, I.N., Komar, P.D., 1977. Threshold of sediment motion under unidirectional currents. Sedimentology 24, 507-527.

Milligan, T.G., Hill, P.S., 1998. A laboratory assessment of the relative importance of turbulence, particle composition, and concentration in limiting maximal floc size and settling behaviour. J. Sea Res. 39, 227-241.

Nezu, I., Nakagawa, H., 1993. Turbulence in open-channel flows. A.A. Balkema, Rotterdam.

Piedra-Cueva, I., Mory, M., Temperville, A., 1997. A race-track recirculating flume for cohesive sediment research. J. Hydraul. Res. 35(3), 378-396.

Raloff, J., 2002. Taming toxic tides: Can we slay poisonous algal blooms with clay? Science News 162, 344-345.

Sanford, L.P., Halka, J.P., 1993. Assessing the paradigm of mutually exclusive erosion and deposition of mud, with examples from upper Chesapeake Bay. Mar. Geol. 114, 37-57.

Sanford, L.P., Maa, J.P.Y., 2001. A unified erosion formulation for fine sediments. Mar. Geol. 179(1-2), 9-23.

Self, R.F.L., Nowell, A.R.M., Jumars, P.A., 1989. Factors controlling critical shears for deposition and erosion of individual grains. Mar. Geol. 86, 181-199.

Sengco, M.R., 2001. The aggregation of clay minerals and marine microalgal cells: physicochemical theory and implications for controlling harmful algal blooms. Doctoral dissertation, Massachusetts Institute of Technology/Woods Hole Oceanographic Institution Joint Program in Oceanography.

Sengco, M.R., Li, A.S., Tugend, K., Kulis, D. and Anderson, D.M., 2001. Removal of red- and brown-tide cells using clay flocculation. I. Laboratory culture experiments with Gymnodinium breve and Aureococcus anophagefferens. Mar. Ecol. Prog. Ser., 210, 41-53. 
Shaw, W.J., Trowbridge, J.H., Williams, A.J. III., 2001. Budgets of turbulent kinetic energy and scalar variance in the continental shelf bottom boundary layer. J. Geophys. Res. 106(C5), 9551-9564.

Shirota, A., 1989. Red tide problem and countermeasures. Int. J. Aquacult. Fish. Technol. 1, 195223.

Shirota, A., 1998. Flocculation of suspended clay particulates, their characteristics and role as the food for marine organisms. Technical Report for Marine Ecology Research Institute, Tokyo, Japan. (In Japanese)

Soballe, D.M., Threlkeld, S.T., 1988. Algal-clay flocculation in turbid waters: variations due to algal and mineral differences. Verh. Int. Ver. Limnol. 23, 750-754.

Sokal, R.R., Rohlf, F.J., 1981. Biometry: the principles and practice of statistics in biological research. W. H. Freeman and Company, New York.

Sutherland, T.F., Grant, J., Amos, C.L., 1998. The effect of carbohydrate production by the diatom Nitzschia curvilineata on the erodibility of sediment. Limnol. Oceanogr. 43(1), 65-72.

Willows, R.I., Widdows, J., Wood, R.G., 1998. Influence of an infaunal bivalve on the erosion of an intertidal cohesive sediment: A flume and modeling study. Limnol. Oceanogr. 43(6), 13321343.

Wulff, A., Sundbaeck, K., Nilsson, C., Carlson, L., Joensson, B., 1997. Effect of sediment load on the microbenthic community of a shallow-water sandy sediment. Estuaries 20(3), 547-558.

Yu, Z., Zou, J., Ma, X., 1994. Application of clays to removal of red tide organisms. 1.

Coagulation of red tide organisms with clays. Chin. J. Oceanol. Limnol. 12(3), 193-200.

Yu, Z., Zou, J., Ma, X., Wang, L., 1995. Study on the kinetics of clays removing red tide organisms. Oceanol. Limnol. Sin. 26(1), 1-6. (in Chinese, with English abstract) 
Table 1. Summary of flume experiments. All experiments were conducted with IMC-P4 clay and the dinoflagellate Heterocapsa triquetra. Clay loadings are reported as dry mass. n/a means not applicable.

\begin{tabular}{|c|c|c|c|c|c|c|c|c|c|}
\hline $\begin{array}{l}\text { Experiment } \\
\text { description }\end{array}$ & $\begin{array}{l}\text { Experiment } \\
\text { run \# }\end{array}$ & $\begin{array}{c}\text { Settling } \\
\text { time (hr) }\end{array}$ & $\begin{array}{c}\text { Flow speed }\left(\mathrm{cm} \mathrm{s}^{-1}\right) \\
\text { during settling }\end{array}$ & $\mathrm{T}\left({ }^{\circ} \mathrm{C}\right)$ & $\begin{array}{c}\text { Salinity } \\
\text { (ppt) }\end{array}$ & $\begin{array}{c}\text { Heterocapsa } \\
\text { cells } \mathrm{mL}^{-1} \times 10^{3} \\
\end{array}$ & $\begin{array}{c}\text { PAC } \\
\left(\mu l \mathbf{L}^{-1}\right) \\
\end{array}$ & $\begin{array}{l}\text { Areal loading } \\
\text { of clay }\left(\mathrm{g} \mathrm{m}^{-2}\right)\end{array}$ & $\begin{array}{c}\text { Concentration } \\
\text { of clay }\left(\mathrm{g} \mathrm{L}^{-1}\right) \\
\end{array}$ \\
\hline \multicolumn{10}{|l|}{ 17-m flume } \\
\hline Clay & 1 & 3 & 0 & 21.5 & 33 & 2.00 & $\mathrm{n} / \mathrm{a}$ & 33.13 & 0.41 \\
\hline Clay & 2 & 3 & 0 & 21.5 & 33 & 2.00 & $\mathrm{n} / \mathrm{a}$ & 33.13 & 0.41 \\
\hline Clay & 3 & 3 & 0 & 21.5 & 33 & 2.00 & $\mathrm{n} / \mathrm{a}$ & 33.13 & 0.41 \\
\hline Clay & 1 & 9 & 0 & 22 & 33 & 1.89 & $\mathrm{n} / \mathrm{a}$ & 44.96 & 0.56 \\
\hline Clay & 2 & 9 & 0 & 22 & 33 & 2.53 & $\mathrm{n} / \mathrm{a}$ & 44.96 & 0.56 \\
\hline Clay & 3 & 9 & 0 & 22 & 33 & 2.43 & $\mathrm{n} / \mathrm{a}$ & 38.22 & 0.48 \\
\hline Clay & 1 & 24 & 0 & 23 & 33 & 2.35 & $\mathrm{n} / \mathrm{a}$ & 56.80 & 0.71 \\
\hline Clay & 2 & 24 & 0 & 23 & 33 & 3.28 & $\mathrm{n} / \mathrm{a}$ & 47.33 & 0.59 \\
\hline Clay & 3 & 24 & 0 & 23 & 33 & 3.23 & $\mathrm{n} / \mathrm{a}$ & 47.33 & 0.59 \\
\hline Clay + PAC & 1 & 3 & 0 & 23.5 & 33 & 2.68 & 5 & 33.13 & 0.28 \\
\hline Clay + PAC & 2 & 3 & 0 & 23.5 & 33 & 1.64 & 5 & 33.13 & 0.28 \\
\hline Clay + PAC & 3 & 3 & 0 & 23.5 & 33 & 1.64 & 5 & 33.13 & 0.28 \\
\hline Clay + PAC & 1 & 9 & 0 & 23.5 & 33 & 1.80 & 5 & 37.86 & 0.32 \\
\hline Clay + PAC & 2 & 9 & 0 & 23.5 & 33.5 & 2.46 & 5 & 37.86 & 0.32 \\
\hline Clay + PAC & 3 & 9 & 0 & 23.5 & 33.5 & 2.43 & 5 & 37.86 & 0.32 \\
\hline Clay + PAC & 1 & 24 & 0 & 24 & 33.5 & 2.39 & 5 & 47.33 & 0.39 \\
\hline Clay + PAC & 2 & 24 & 0 & 24 & 33.5 & 2.77 & 5 & 47.33 & 0.39 \\
\hline Clay + PAC & 3 & 24 & 0 & 24 & 33.5 & 3.36 & 5 & 47.33 & 0.39 \\
\hline \multicolumn{10}{|c|}{ Racetrack flume } \\
\hline Clay & 1 & $3,3,9$ & 3 & 23 & 30 & 0.75 & $\mathrm{n} / \mathrm{a}$ & 33.21 & 0.28 \\
\hline Clay + PAC & 1 & $3,3,9$ & 3 & 23 & 30 & 0.33 & 5 & 33.21 & 0.28 \\
\hline Clay & 1 & $3,3,9$ & 10 & 21 & 30 & 0.51 & $\mathrm{n} / \mathrm{a}$ & 33.21 & 0.28 \\
\hline Clay + PAC & 1 & $3,3,9$ & 10 & 22 & 30 & 0.70 & 5 & 33.21 & 0.28 \\
\hline Clay & $2 *$ & 3 & $20 * *$ & 20.5 & 30 & 0.15 & $\mathrm{n} / \mathrm{a}$ & 33.21 & 0.28 \\
\hline
\end{tabular}

* Run 1 lost due to power outage.

** Initially at $20 \mathrm{~cm} \mathrm{~s}^{-1}$ and then decreased by $2 \mathrm{~cm} \mathrm{~s}^{-1}$ every 3 hours. 
Table 2. Critical bed shear stress $\left(\tau_{0 c r i t}\right)$ for three stages of transport of clay/algal flocs in the 17m flume. Values are mean \pm std. devn. for three replicate flume runs. Results for resuspension stress are plotted in Figure 2. For critical shear velocity, $u *_{c r i t}=\left(\tau_{0 \text { crit }} / \rho\right)^{1 / 2}$, substitute $\rho=$ $1.0225 \mathrm{~g} \mathrm{~cm}^{-3}$.

\begin{tabular}{lcccc} 
& & \multicolumn{3}{c}{$\tau_{\boldsymbol{0} \text { crit }}(\mathbf{P a})$} \\
\cline { 3 - 5 } $\begin{array}{l}\text { Experiment } \\
\text { description }\end{array}$ & $\begin{array}{c}\text { Settling } \\
\text { time (hr) }\end{array}$ & $\begin{array}{c}\text { Initial } \\
\text { motion }\end{array}$ & Bedload & Resuspension \\
\hline & & & & \\
Clay & 3 & $0.017 \pm 0.001$ & $0.028 \pm 0.003$ & $0.069 \pm 0.006^{*}$ \\
Clay & 9 & $0.019 \pm 0.001$ & $0.029 \pm 0.000$ & $0.081 \pm 0.002$ \\
Clay & 24 & $0.019 \pm 0.001$ & $0.032 \pm 0.002$ & $0.088 \pm 0.005$ \\
Clay + PAC & 3 & $0.018 \pm 0.000$ & $0.026 \pm 0.001$ & $0.059 \pm 0.002$ \\
Clay + PAC & 9 & $0.017 \pm 0.000$ & $0.027 \pm 0.002$ & $0.068 \pm 0.004$ \\
Clay + PAC & 24 & $0.019 \pm 0.001$ & $0.031 \pm 0.001$ & $0.071 \pm 0.002$ \\
\hline
\end{tabular}

* Contains an outlier based on post-experiment observations of video. 
Table 3. Two-way ANOVA for the 17-m flume results for resuspension stress for clay/algal flocs (plotted in Figure 2). The two sources of variation in the $3 \times 2$ factorial design were settling time $(3,9$, or $24 \mathrm{hr})$ and PAC (presence or absence).

\begin{tabular}{lccccc} 
Source & df & SS & MS & F & P \\
\hline Settling time & 2 & 0.000776 & 0.000388 & 23.99 & 0.000064 \\
PAC & 1 & 0.000751 & 0.000751 & 46.42 & 0.000019 \\
Interaction & 2 & 0.000036 & 0.000018 & 1.12 & 0.36 \\
Error & 12 & 0.000194 & 0.000016 & & \\
Total & 17 & 0.0018 & & & \\
\hline
\end{tabular}


Table 4. Using racetrack flume results to model erosion rate as $E=M\left(\tau_{b} / \tau_{0 \text { crit }}-1\right)$. Values are single estimates derived from OBS "slope analysis" (depicted in Figure 4). Total volume 2052 L and area $17.1 \mathrm{~m}^{2}$ in racetrack flume. $\mathrm{M}$ is presented in units comparable to Sanford and Halka (1993).

\begin{tabular}{|c|c|c|c|c|c|c|c|}
\hline $\begin{array}{l}\text { Experiment } \\
\text { description }\end{array}$ & $\begin{array}{c}\text { Flow speed }\left(\mathrm{cm} \mathrm{s}^{-1}\right) \\
\text { during settling }\end{array}$ & $\begin{array}{c}\text { Resuspension } \\
\text { event }\end{array}$ & $\begin{array}{c}\text { Critical stress, } \\
\tau_{0 \text { crit }}(\mathrm{Pa}) \\
\end{array}$ & $\begin{array}{c}\text { Stress }\left(\tau_{b}\right) \text { at max } \\
\text { sediment input (Pa) }\end{array}$ & $\begin{array}{l}\text { Increase in sediment } \\
\text { concentration }\left(\mathrm{g} \mathrm{L}^{-1}\right)\end{array}$ & $\begin{array}{l}\text { Change in } \\
\text { time (hr) }\end{array}$ & $\begin{array}{c}\mathrm{M} \\
\left(\mathrm{mg} \mathrm{cm}^{-2} \mathrm{hr}^{-1}\right) \\
\end{array}$ \\
\hline \multirow{3}{*}{ Clay } & \multirow{3}{*}{3} & $1^{\mathrm{st}} 3 \mathrm{hr}$ & 0.040 & 0.060 & 0.068 & 0.27 & 6.1 \\
\hline & & $2^{\text {nd }} 3 \mathrm{hr}$ & 0.034 & 0.060 & 0.108 & 0.37 & 4.6 \\
\hline & & $9 \mathrm{hr}$ & 0.034 & 0.060 & 0.115 & 0.42 & 4.3 \\
\hline \multirow{3}{*}{ Clay + PAC } & \multirow{3}{*}{3} & $1^{\text {st }} 3 \mathrm{hr}$ & 0.034 & 0.053 & 0.081 & 0.36 & 4.8 \\
\hline & & $2^{\text {nd }} 3 \mathrm{hr}$ & 0.034 & 0.053 & 0.107 & 0.33 & 6.9 \\
\hline & & $9 \mathrm{hr}$ & 0.034 & 0.053 & 0.101 & 0.35 & 6.2 \\
\hline \multirow{3}{*}{ Clay } & \multirow{3}{*}{10} & $1^{\mathrm{st}} 3 \mathrm{hr}$ & 0.060 & 0.083 & 0.097 & 0.32 & 9.4 \\
\hline & & $2^{\text {nd }} 3 \mathrm{hr}$ & 0.053 & 0.083 & 0.102 & 0.43 & 5.0 \\
\hline & & $9 \mathrm{hr}$ & 0.060 & 0.092 & 0.080 & 0.36 & 4.9 \\
\hline \multirow{3}{*}{ Clay + PAC } & \multirow{3}{*}{10} & $1^{\text {st }} 3 \mathrm{hr}$ & 0.053 & 0.083 & 0.058 & 0.33 & 3.7 \\
\hline & & $2^{\text {nd }} 3 \mathrm{hr}$ & 0.046 & 0.083 & 0.042 & 0.45 & 1.4 \\
\hline & & $9 \mathrm{hr}$ & 0.046 & 0.092 & 0.038 & 0.52 & 0.9 \\
\hline
\end{tabular}


Table 5. Clay mass deposition and algal removal efficiency (RE) in the racetrack flume. Values are reported for the $\%$ of clay mass that deposited during the three settling periods (as depicted in Figure 3). RE values are based on the cell counts just prior to clay addition (shown in Figure 5).

\begin{tabular}{lccccccc} 
Experiment & \multicolumn{2}{c}{$\begin{array}{c}\text { Flow speed }\left(\mathbf{c m ~ s}^{\mathbf{- 1}}\right) \\
\text { description }\end{array}$} & \multicolumn{2}{c}{$\%$ of clay mass that deposited } & \multicolumn{3}{c}{ Removal efficiency (RE) of Heterocapsa } \\
\hline \multirow{2}{*}{ during settling } & $\mathbf{1}^{\text {st }} \mathbf{3} \mathbf{~ h r}$ & $\mathbf{2}^{\text {nd }} \mathbf{3} \mathbf{~ h r}$ & $\mathbf{9} \mathbf{~ h r}$ & $\mathbf{1}^{\text {st }} \mathbf{3} \mathbf{~ h r}$ & $\mathbf{2}^{\text {nd }} \mathbf{3} \mathbf{~ h r}$ & $\mathbf{9} \mathbf{h r}$ \\
Clay & 3 & $94 \%$ & $94 \%$ & $96 \%$ & $100 \%$ & $98 \%$ & $99 \%$ \\
Clay + PAC & 3 & $94 \%$ & $95 \%$ & $96 \%$ & $78 \%$ & $25 \%$ & $19 \%$ \\
Clay & 10 & $79 \%$ & $72 \%$ & $86 \%$ & $89 \%$ & $78 \%$ & $90 \%$ \\
Clay + PAC & 10 & $39 \%$ & $31 \%$ & $40 \%$ & $28 \%$ & $15 \%$ & $69 \%$ \\
Clay & 20 & $1 \%$ & & & $41 \% *$ & & \\
\hline
\end{tabular}

\footnotetext{
* Cell counts may be low due to large amount of clay in sample.
} 
Figure captions

Figure 1. A scenario for clay/algal flocculation, deposition, and resuspension. The dashed square indicates a study volume in which environmental impacts are monitored. (1) Clay is sprayed on the water surface. (2) Clay and single-celled algae flocculate in the water column; some flocs are advected laterally out of the study volume. (3) Clay/algal flocs settle and accumulate on the sea floor. (4) Increased flow leads to resuspension and lateral advection of flocs.

Figure 2. Resuspension stress for clay/algal flocs in the 17-m flume. Each symbol indicates mean \pm std. devn. for three replicate flume runs. (Values listed in Table 2.)

Figure 3. Optical backscatter (OBS) plots for racetrack flume runs. Linear fits to 2-min subsets of data are superimposed on plots A,B,D, and E.

A,B. Paddle speed $3 \mathrm{~cm} \mathrm{~s}^{-1}$. OBS at $3.4 \mathrm{~cm}$ above bottom. A. No PAC. The highlighted box indicates data plotted in Figure 4. B. With PAC.

C,D. Paddle speed $10 \mathrm{~cm} \mathrm{~s}^{-1}$. C. No PAC. OBS at $6 \mathrm{~cm}$ a.b. Gaps indicate manual displacement of the OBS to 3.4 and $8 \mathrm{~cm}$ a.b. during resuspension events. D. With PAC. OBS at $8 \mathrm{~cm}$ a.b. E. Paddle speed $20 \mathrm{~cm} \mathrm{~s}^{-1}$. No PAC. OBS at $3.4 \mathrm{~cm}$ a.b. Paddle speed was decreased by $2 \mathrm{~cm} \mathrm{~s}^{-}$ ${ }^{1}$ every three hours. Arrows indicate decreases to 12,10 , and $8 \mathrm{~cm} \mathrm{~s}^{-1}$.

Figure 4. OBS “slope analysis” for the first resuspension event in Figure 3A. Upper panel shows the slope of linear fits to 2-min subsets of OBS data. Dashed lines indicate first increase 
in OBS slope and maximum slope (upper panel) and intersection with bed shear stress calibrated to paddle speed in the flume (lower panel). Each step in the plot for bed shear stress represents a $1 \mathrm{~cm} \mathrm{~s}^{-1}$ increase in paddle speed (from 3 to $25 \mathrm{~cm} \mathrm{~s}^{-1}$ ).

Figure 5. Cell counts for racetrack flume runs. Symbols indicate mean \pm range of 2 or 3 counts of each 50-ml sample of flume water. Note log scale. Mean values were used to determine removal efficiency (RE) reported in Table 5. 
Figure 1

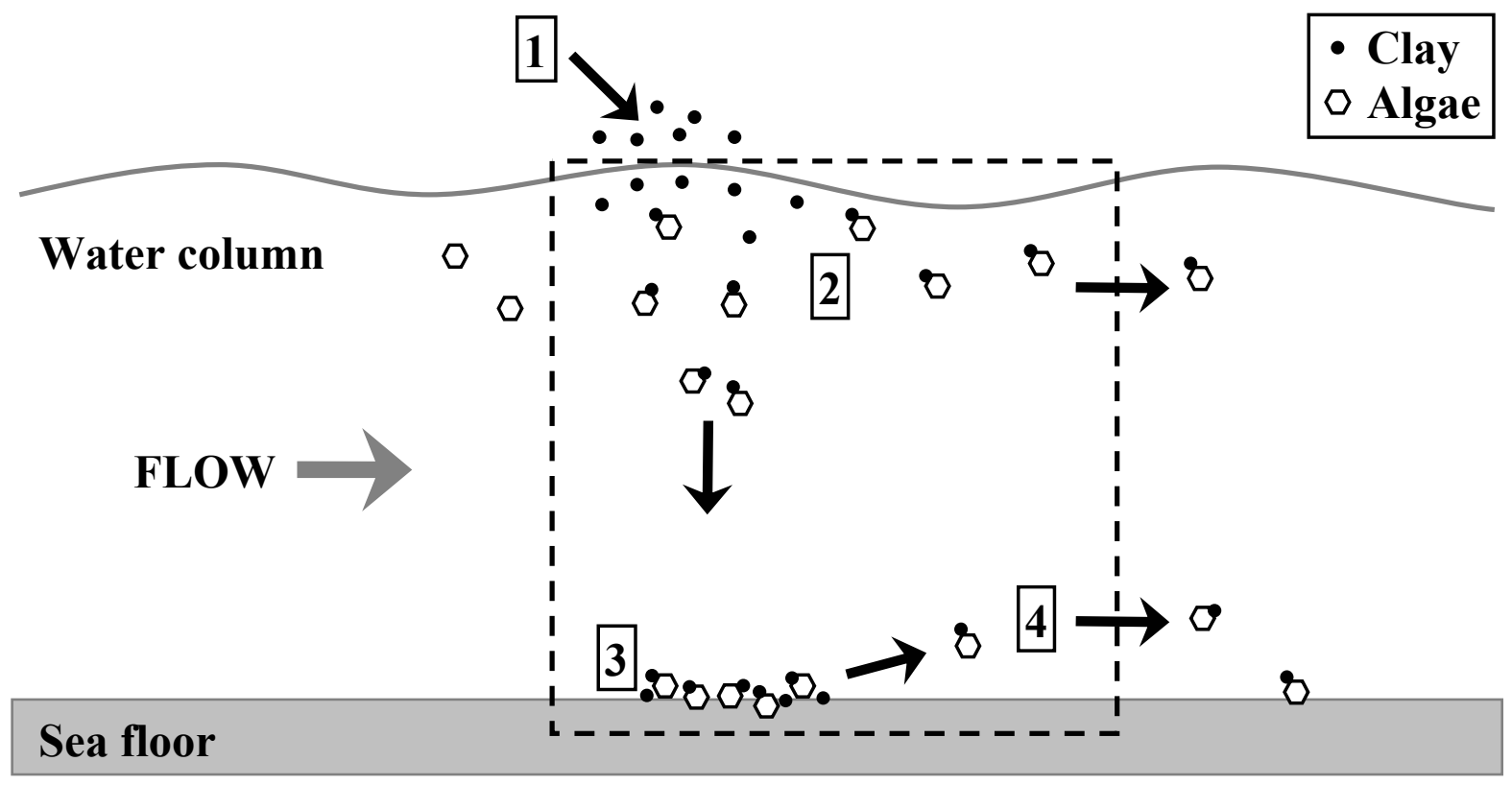


Figure 2

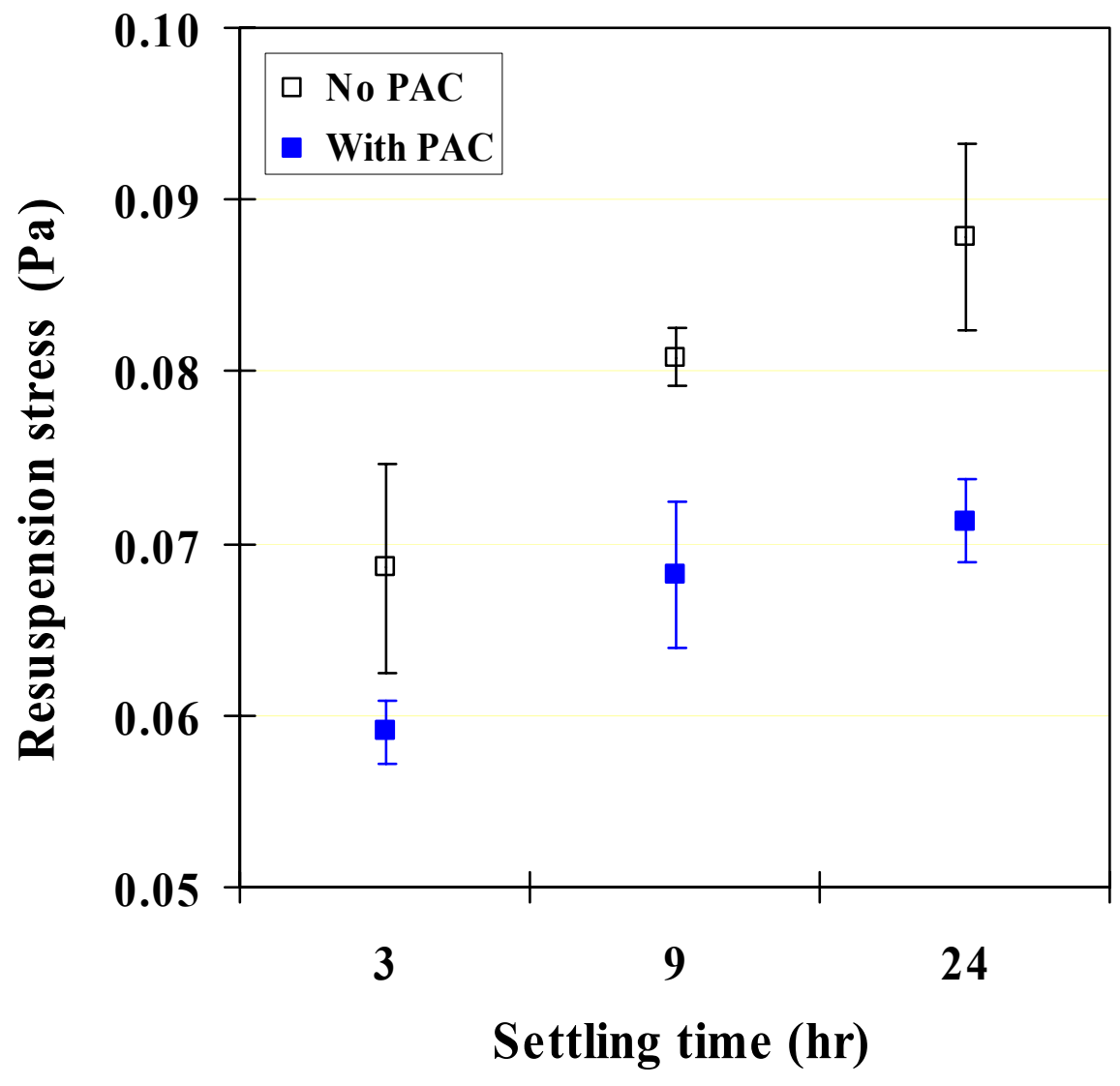


Figure 3
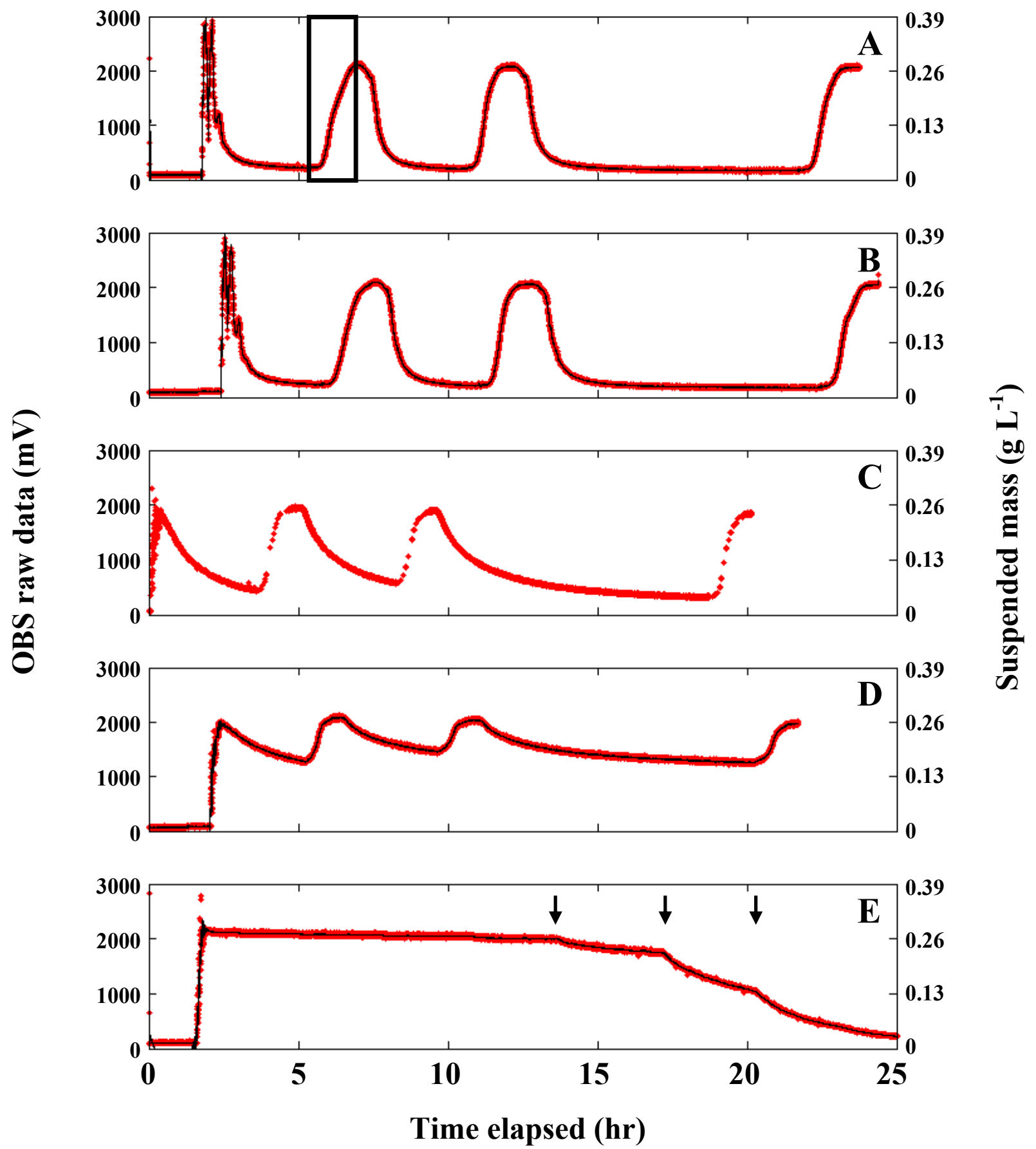
Figure 4
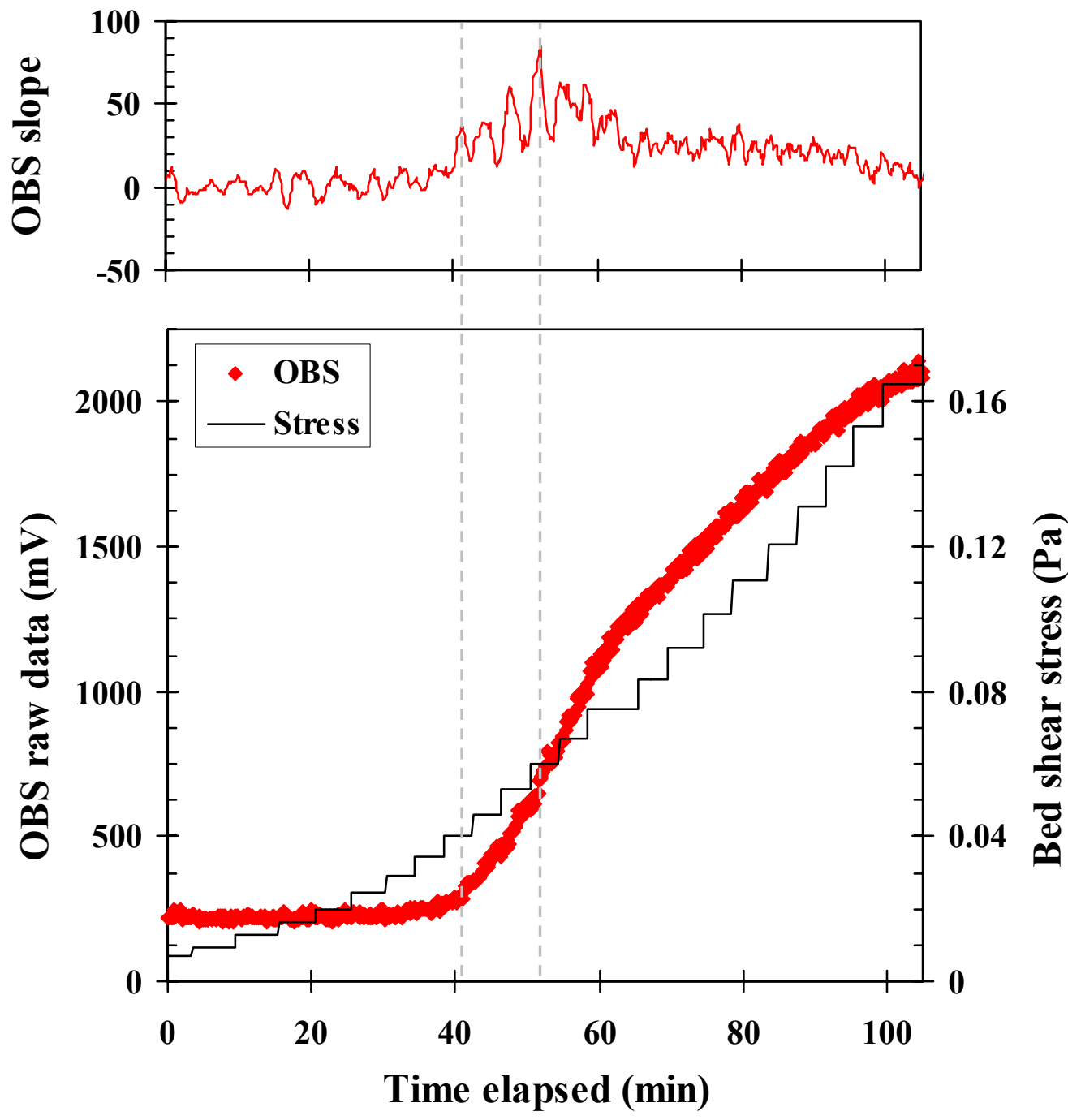
Figure 5

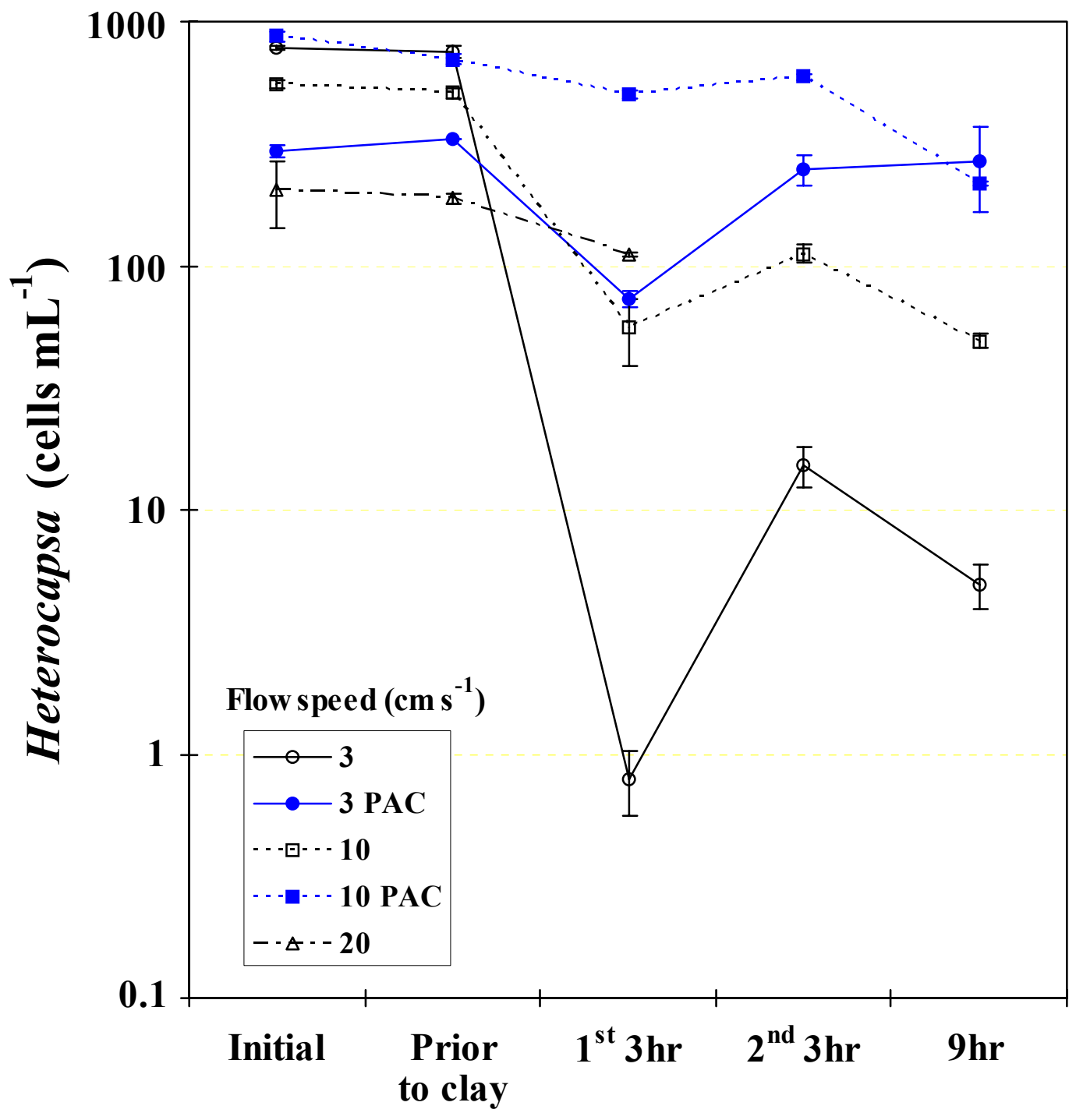

